\title{
Effectiveness of stenting with an intubation tube for a subglottic mass in an infant
}

\author{
Yuji Fujita, ${ }^{1}$ Hideki Hirabayashi, ${ }^{2}$ George Imataka, ${ }^{1}$ Shigemi Yoshihara'
}

'Department of Pediatrics, Dokkyo Medical University, Shimotsuga, Tochigi, Japan ${ }^{2}$ Department of

Otorhinolaryngology—Head and Neck Surgery, Dokkyo Medical University, Shimotsuga, Tochigi, Japan

\section{Correspondence to} Dr Yuji Fujita;

fujitay@dokkyomed.ac.jp

Accepted 12 June 2020

\section{DESCRIPTION}

A 1-month-old girl was referred to the emergency department owing to stridor and severe respiratory distress. We suspected pertussis owing to a whooping-like cough and stridor. However, 5 days of azithromycin administration was not effective in ameliorating her stridor. Moreover, loop-mediated isothermal amplification for pertussis was negative. Therefore, we performed bronchofiberscopy, and bulging in the subglottic tracheal membrane was observed (figure 1). The surface of the bulging area comprised the tracheal mucosa. Since her respiratory distress intensified, the girl was intubated. Intubation was performed smoothly, without resistance. After tracheal intubation, her stridor disappeared quickly and her respiratory status improved immediately.

Neck MRI showed a compressed mass, with a high T2 signal; thus, haemangioma and lymphangioma were suspected (figure 2). The mass may have been soft, based on its compression by the intubation tube. The patient's parents did not provide consent for tracheostomy. Therefore, she was observed under tracheal intubation, and the stenting effect of the intubation tube was closely monitored. Neck MRI at 13 days after intubation showed no mass. We performed extubation and prepared for an emergency tracheostomy 20 days after intubation. After extubation, she did not present with respiratory distress and was discharged 1 month later. She has remained free of recurrence at the age of 6 months.

Laryngomalacia is known to be a common cause of stridor during the neonatal period or infancy. However, subglottic diseases such as tracheomalacia and subglottic haemangioma should also be considered carefully when performing bronchofiberscopy. ${ }^{1}$

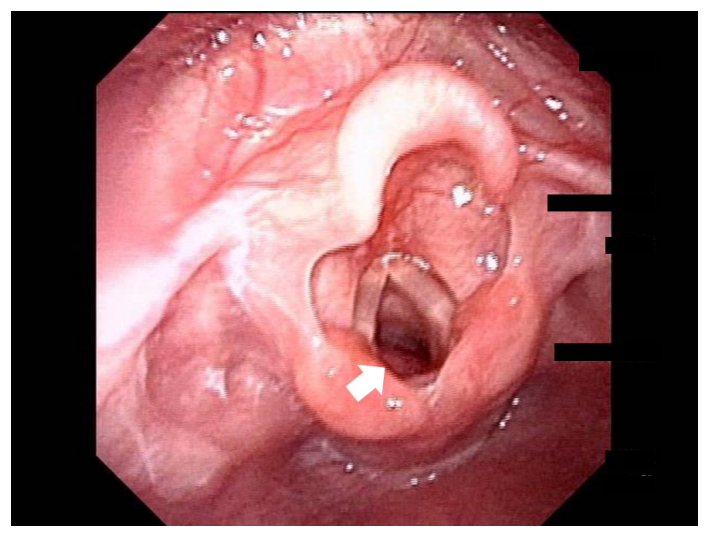

Figure 1 Bulging of the subglottic tracheal membrane (white arrow) is observed on bronchofiberscopy.

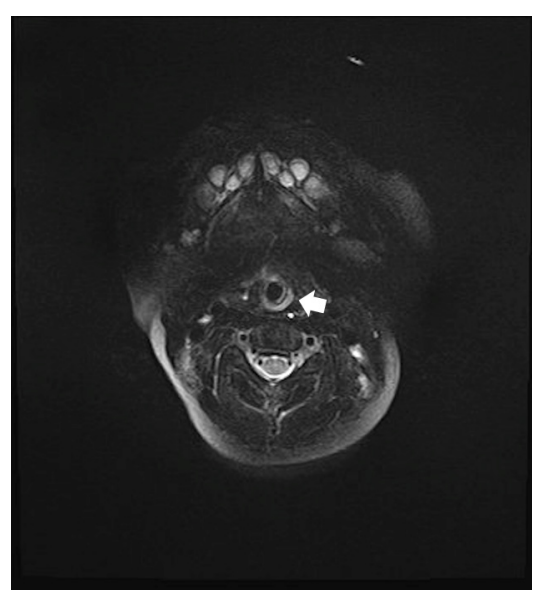

Figure 2 Neck MRI showing a compressed mass (white arrow).

The possibility of vascular compression of the trachea should be considered because the surface of the bulging area comprises the tracheal mucosa. ${ }^{2}$ However, in our case, cardiac ultrasonography and MRI revealed no abnormality of vessels. MRI findings suggested that the mass content might have been liquid, which indicated the possibility of haemangioma and lymphangioma. There are some case reports indicating that these diseases in the subglottic region can cause life-threatening upper airway obstruction. ${ }^{34}$ This case could not be diagnosed by MRI and endoscopic findings, and a tracheotomy was required for biopsy. However, even if a biopsy had been performed after tracheostomy, we may not have been able to diagnose the type of mass because the content of this mass may have been liquid. Therefore, stenting with

\section{Patient's perspective}

We were worried about the tracheostomy. As a result, we were glad that a tracheostomy had not been performed.

\section{Learning points}

Paediatricians should consider a possibility for a subglottic mass in a patient with stridor and respiratory distress.

- Paediatricians should consider carefully whether to perform biopsy in subglottic lesions.

- Stenting with an intubation tube for a subglottic mass may be expected before tracheostomy. 
long-term tracheal intubation may be a worthwhile treatment option for a subglottic mass before tracheostomy.

Contributors YF: drafted and revised the initial manuscript. $\mathrm{HH}, \mathrm{GI}$ and SY: critically revised the manuscript for important intellectual content. All authors read and approved the final manuscript.

Funding The authors have not declared a specific grant for this research from any funding agency in the public, commercial or not-for-profit sectors.

Competing interests None declared.

Patient consent for publication Parental/guardian consent obtained.
Provenance and peer review Not commissioned; externally peer reviewed.

\section{REFERENCES}

1 Pfleger A, Eber E. Assessment and causes of stridor. Paediatr Respir Rev 2016:18:64-72.

2 Ida JB, Thompson DM, stridor P. Pediatric stridor.. Otolaryngol Clin North Am 2014:47:795-819.

3 Ajmi H, Mama N, Hassayoun S, et al. Life-Threatening subglottic hemangioma in an infant successfully treated with propranolol. Arch Pediatr 2018.

4 Kenton A, Duncan N, Bhakta K, et al. Laryngeal lymphatic malformation in a newborn. J Perinatol 2003;23:567-71

Copyright 2020 BMJ Publishing Group. All rights reserved. For permission to reuse any of this content visit

https://www.bmj.com/company/products-services/rights-and-licensing/permissions/

BMJ Case Report Fellows may re-use this article for personal use and teaching without any further permission.

Become a Fellow of BMJ Case Reports today and you can:

- Submit as many cases as you like

Enjoy fast sympathetic peer review and rapid publication of accepted articles

- Access all the published articles

Re-use any of the published material for personal use and teaching without further permission

Customer Service

If you have any further queries about your subscription, please contact our customer services team on +44 (0) 2071111105 or via email at support@bmj.com.

Visit casereports.bmj.com for more articles like this and to become a Fellow 